УДК 349.46

DOI https://doi.org/10.32849/2663-5313/2020.3.18

\title{
Дар'я Кондратенко,
}

аспірант кафедри земельного та аграрного права

Начіонального юридичного університету імені Ярослава Мудрого

\section{ОКРЕМІ ПИТАННЯ ОБЛІКУ ЗЕМЕЛЬ ЯК ПРАВОВОЇ КАТЕГОРІї}

У статті розглядаються актуальні питання організаиії ефективного збалансованого обліку земель на території України. Проаналізовані елементи обліку земельних ресурсів з метою повного і безперервного, об'єктивного і системного облікового відображення вказаної правової категорії. Досліджені окремі питання обліку земель, а також узагальнено основні поняття, які використовуються у сфері земельно-правових відносин.

Розглядається основна мета і завдання проведення земельного обліку на просторах України. Визначені вади методологічного та методичного підходів до побудови обліково-кадастрового забезпечення земель. Окреслені шляхи організачії аналітичного земельного обліку та зазначена доцільність запровадження галузевих стандартів у земельному обліку як правовій категорії.

Також приділена достатня увага необхідності правильного та своєчасного заповнення обліковокадастрової системи достовірною інформачією, що стосується якісних та кількісних характеристик земельних ресурсів (ділянок). Виявлено найголовніші проблеми у формуванні й веденні земельного обліку якості земельних ресурсів та наведені основні шляхи їх вирішення.

у роботі земельний облік розглядається з точки зору управлінської функиії як складового елементу механізму земельного адміністрування. Визначено, що за його допомогою забезпечується оптимальне використання та охорона земель відповідно до їх иільового призначення з урахуванням усіх форм власності і господарювання.

Структурний аналіз правового змісту основних понять обліково-кадастрових категорій, які використовуються у сфері земельних правовідносин, є необхідним для виявлення й усунення термінологічних помилок, гармонізаиї̈ понятійного апарату та сприяє вивченню стану обліку земельних pecypcis.

Ключові слова: облік земель, земельні ресурси, об'єкт обліку, земельні відносини, земельні ділянки.

Постановка проблеми. Земельні ресурси завжди виступали головним джерелом задоволення першорядних людських потреб та є складовою частиною виробничого потенціалу народного господарства.

Земельний облік, як один із різновидів обліку природних ресурсів, є одним з основних видів народно-господарського обліку, який разом із бухгалтерським, оперативним і статистичним становить єдину узгоджену систему обліку. При цьому кожний вид народно-господарського обліку вирішуе свої завдання, використовуючи, поряд із загальними, свої особливі прийоми і методи [5, c. 21].

У сучасних умовах становлення ринку землі в Україні облік землі набуває актуальності у зв'язку з потребою отримання користувачами земельних ресурсів достовірної й точної інформації про їхню якість, оцінку, стан та ефективність використання.

Стан дослідження. Науковій проблематиці, що пов'язана з дослідженням і вивчен- ням обліку земельних ресурсів, у різний час приділяли увагу такі вітчизняні та зарубіжні науковці, як: Д. І. Бабміндра, Д. В. Буша, М. М. Бахуринська, Р. Й. Гулько, Н. О. Грабовець, І. В. Дегтярьов, Г. Л. Землякова, М. О. Ільїна, Н. В. Ільків, І. О. Іконицька, Т. М. Лебедєва, Т. В. Лісова, Р. І. Марусенко, А. Г. Мартин, В. Л. Суровцев, М. Г. Ступень, А. С. Чешев, С. В. Шарапова та інші.

В умовах розвитку національної економіки формування різноманітних організаційно-правових форм господарювання 3 метою передачі землі у власність (користування) громадян, а також проведення земельно-правової реформи, передусім, пов'язано з процесом парцеляції земельних ділянок у зв'язку з утворенням великої їх кількості. Саме в таких умовах суттєво зростає значення державного управління земельними ресурсами, ефективність якого багато в чому залежить від земельно-кадастрових даних, зокрема від досконалої системи обліку земель [11, с. 5-6]. При цьому земля виступає 
товаром земельного ринку, а тому все більшої ваги набуває якісна оцінка земельної ділянки, яка із теоретичного простору переходить у практичну площину, стаючи ядром економіки держави.

Основною метою статті $є$ дослідження основних характеристик та облікових категорій у сфері земельно-правових відносин в Україні, а також надання певних рекомендацій щодо налагодження земельного обліку з метою забезпечення ефективного земельного адміністрування.

Виклад основного матеріалу. Важливою передумовою успішного й ефективного функціонування в Україні ринку землі та проведення обліково-кадастрової реєстрації земельних ресурсів виступає їх ефективний облік (земельних ділянок та прав на них), який є підгрунтям ефективного і раціонального використання земельних ресурсів, їх відтворення, управління ними, а також їх охорони.

Натепер основу обліково-реєстраційної системи земель в Україні становить Державний земельний кадастр. У ньому відображається суб'єктивна інформація щодо земельних ділянок, отримана у результаті проведення обліку земельних ресурсів. Така інформація необхідна передовсім для здійснення державного контролю за відтворенням, охороною та використанням земель. Тому питання правового забезпечення кадастрового обліку земель і досі залишається актуальним.

Тільки впорядкований та законодавчо унормований процес здійснення у сфері земельно-правових відносин обліково-реєстраційної діяльності може стати запорукою запровадження і функціонування прозорого механізму обігу земель у ринкових умовах та дієвого механізму управління ними.

У контексті сказаного доречно зазначити, що натепер, на жаль, в Україні відсутнє законодавчо-правове визначення обліку земель. Однак у науковій літературі трапляються різні позиції стосовно визначення цього терміна, серед яких можна виділити такі:

1. Облік земель розглядається за кількісними показниками. Наприклад, А. С. Чешев та I. П. Фесенко земельний облік розглядають як вид державного заходу з метою накопичення, систематизації та аналізу різноманітних відомостей щодо кількості, розміщення, природного стану, господарського положення та використання земельних ресурсів [12, с. 83$]$.

I. А. Іконницька вважає, що облік земель це збір, систематизація, зберігання та поновлення відомостей про наявність, стан і вико- ристання земельного фонду [2, с. 85]. А інша вчена, Т. М. Лебедєва зазначала, що «облік земельних ресурсів - це певно коло дій уповноваженого органу державної влади, яке спрямоване на внесення до державного земельного кадастру значимої інформації, іiї обробку, систематизацію та оновлення інших юридичних відомостей у системі державного земельного кадастру» [4, с. 235]

Інша вчена, К. В. Симонова, визначала кадастровий облік земель як певні дії органу державної виконавчої влади, уповноваженого здійснювати діяльність щодо внесення у державний земельний кадастр юридично значимих відомостей про земельні ресурси (земельну ділянку) [9, с. 21]. Але, на мою думку, більш слушним видається визначення, відповідно до якого облік земель - це комплекс державних заходів у системі земельного кадастру, що спрямований на отримання, систематизацію та аналіз відомостей (інформації) про кількість, територіальне розміщення, а також господарське використання земель. До завдань обліку входить збір інформації про земельні ресурси, іiї систематизація, аналіз, зберігання, оновлення, а також надання її користувачам.

2. Облік земель розглядається за якісними показниками. Зокрема, О. В. Сакаль визначає земельний облік як спеціальну управлінську функцію, яка є істотним елементом механізмів земельного адміністрування, що здійснюється 3 метою забезпечення оптимального використання та охорони земель будь-якого цільового призначення незалежно від форми власності та господарювання [7, с. 57].

Т. М. Ситнік вказував, що облік земель у населених пунктах, зайнятих зеленими насадженнями, відображається у відомостях і документах, які характеризують кожну земельну ділянку у межах населених пунктів, на якій розміщені дерева, чагарники, квіти, трав'яна рослинність та інші об'єкти рослинного світу штучного і природного походження, за площею, природними і набутими властивостями, які впливають на їх природну цінність й продуктивність, а також розподіл таких земель по власниках і землекористувачах [10, с. 277].

Таким чином, облік земель на державному рівні - це найважливіша частина фундаментального земельну кадастру, яка застосовується у межах всіх категорій земель. Вона виконує практичні завдання у сферах землекористування та внутрішньогосподарського використання щодо підвищення рівня ефективності державного управління у вказаній площині.

Основним елементом обліку земельних ресурсів є вид земель (угіддя), окремі 
ділянки, які $є$ одиницями рахунку при земельному обліку 3 метою отримання загальних даних за видами земель, земельної ділянки (землекористування) тощо. Виходячи із цього, основними завданнями земельного обліку можна вважати:

- отримання, проведення систематизації та аналізу усіх природних ресурсів, що наявні (розташовані) на земельній ділянці;

- проведення певного кола польових робіт щодо зйомок і обстеження земельних ділянок з метою отримання необхідних земельно-облікових даних;

- визначення кількісно-якісних показників земель та надання необхідних даних про земельні ресурси;

- виготовлення земельно-облікових планових матеріалів, а також внесення первинних даних у земельно-облікові документи.

3. Облік земель в аспекті співвідношення кількісних та якісних показників. Так, прихильники вказаного напряму дають визначення обліку земель як систематизації, зберігання та оновлення відомостей про кількість і якість земельного фонду. Якість враховується за класами, гранулометричним станом грунтів і ознаками, що впливають на їхню родючість. Отже, земельний облік являє собою процес збирання тазберігання відомостей про станземельного фонду України на певному етапі її історичного розвитку. Тобто, облік земель - це перш за все їх кількісне відображення та якісна характеристика.

На мій погляд, перші два запропоновані напрями звужують поняття обліку земель, що $€$ недоцільним, натомість останній напрям є найбільш вдалим, та таким, що відповідає сучасному українському законодавству i потребам сьогодення. Тому, узагальнюючи вищенаведені тлумачення поняття обліку земель, можна дійти логічного висновку, що облік земель - це діяльність спеціально уповноважених державних органів, яка спрямована на здійснення заходів $з$ отримання, систематизації та аналізу відомостей щодо кількісно-якісних характеристик земельних ділянок.

В Україні правову основу обліку земель становить низка чинних нормативно-правових актів, які регулюють ті чи інші питання, пов'язані 3 обліком земель. Розглянемо деякі з них.

Передусім слід зазначити, що принципові положення, які стосуються обліку земель як правової категорії, закріплені в Земельному кодексі України (далі - ЗК України). Так, стаття 203 ЗК України [1] визначає, що облік земель - це обов'язкова складова державного земельного кадастру.
Якщо проаналізувати норми ЗК України, то можна визначити, що існує як кількісний облік (зазначається, наприклад, склад земельних угідь), так і якісний (певні характеристики земельних угідь за природними властивостями, ступенем техногенного забруднення грунтів та ін.).

Деталізацію та конкретизацію положень щодо обліку земель, закріплених Земельним кодексом України, здійснює Закон України «Про Державний земельний кадастр», який визначає правові, економічні та організаційні основи діяльності у сфері Державного земельного кадастру [6].

Метою цього Закону є забезпечення необхідною інформацією органів державної влади та місцевого самоврядування, зацікавлених організацій, підприємств й установ, громадян 3 метою регулювання земельноправових відносин, раціонального землекористування й охорони земель, визначення цінності земель як цілісної складової частини природних ресурсів та розміру плати за землю, контролю за охороною і використанням земельних ресурсів, економічного й екологічного обгрунтування проектів землеустрою і бізнес-планів.

Проведення обліку земельних ресурсів проводиться відповідно до державних стандартів, норм і правил, що визначаються спеціально уповноваженими органами виконавчої влади або органами місцевого самоврядування з питань земельних ресурсів. При цьому вказані стандарти, правила і норми не повинні суперечити вимогам Закону України «Про стандартизацію» від 05 червня 2014 року та мають бути узгодженими зі спеціально уповноваженими органами виконавчої влади із питань містобудування, статистики, природних ресурсів, аграрної політики та екології.

У нашій державі облік кількості земельних ресурсів (ділянок) інтегровано у єдину систему державних статистичних спостережень, нормативно-правовою основою якої $€$ Закон України «Про державну статистику» від 17 вересня 1992 року.

Необхідно зауважити, що в умовах сьогодення у державі найбільш суттєвими вадами кадастрового обліку земельних ресурсів $\epsilon$ його формально-статистичний характер, а також дискретність кадастрових даних. Крім того, ще одним із недоліків чинної української земельно-кадастрової системи є наявність процедури збирання інформації стосовно земельні ділянки та фактичний стан використання земельних ресурсів, які безпосередньо стосуються реалізації принципу документування усіх відомостей, що містяться у Державному земельному кадастрі. 
Отже, в Україні сьогодні в органах Державного геологічного кадастру простежується відсутність повної і необхідної інформації про значну частину земель. Водночас поряд із цим більшість наявних відомостей про земельні ділянки (землі) є викривленими. Про вказаний факт свідчить Єдиний державний реєстр судових рішень, що містить низку рішень судів у справах, зокрема, щодо виправлення помилок.

Також аналіз правових норм розділу VII Закону України «Про Державний земельний кадастр» може свідчити про те, що цим Законом фактично визнається масштаб проблеми, адже у Прикінцевих і перехідних положеннях вказаного Закону навіть передбачений певний правовий механізм для виправлення помилок (описок), які трапляються на момент запровадження у дію земельного кадастру.

Відповідно до пункту 5 статті 33 Закону України «Про Державний земельний кадастр» відомості, які стосуються кількості та якості земель, узагальнюються центральним органом виконавчої влади 3 питань земельних ресурсів. Така узагальнена інформація на безоплатній основі надається органам державної влади та місцевого самоврядування відповідно до вимог Порядку ведення Державного земельного кадастру в Україні. До речі, передача вказаної інформації безоплатно - це важлива новела в українському земельному законодавстві, оскільки більша частина органів місцевого самоврядування у процесі розпорядження земельними ресурсами фактично діють всліпу, не маючи при цьому жодних систем обліку таких земель. Насамперед закритість відомостей, що стосуються земель, перешкоджає визначенню необхідних перспектив розвитку конкретних місцевостей і здійсненню природоохоронних заходів.

Також слід зазначити, що найбільш вдалим кроком у процесі вдосконалення земельно-облікової діяльності та розвитку системи безперервного оновлення юридично значимої інформації в електронній системі ведення Державного земельного кадастру стало закріплення на законодавчому рівні вимог до змісту, структури і технічних характеристик електронного документа у Постанові Кабінету Міністрів України від 17 жовтня 2012 року № 1051 «Про затвердження Порядку ведення Державного земельного кадастру», яких у попередній редакції зазначеного Порядку ще не було.

За період дії Закону України «Про землеустрій» із 52 стандартів державних будівельних норм, які повинні бути розроблені, розроблено лише три. Це зумовлено відсутністю загальнодержавної програми i, як наслідок, передбачених бюджетних коштів на розроблення технічної документації. Тобто нагальною проблемою залишається відсутність чіткого механізму проведення ефективного обліку земель, який має бути детально прописаний у відповідних підзаконних нормативно-правових актах та реалізований на практиці.

Також слід зауважити, що нині згідно 3 чинним вітчизняним законодавством в Україні залишаються розділеними між двома органами державної влади та двома реєстраційними системами функції ведення кадастру та функції реєстрації прав на землю, тоді як у більшості країн світу обидва реєстри об'єднано в універсальну кадастровореєстраційну систему, яка поєднує функції обліку нерухомості (кадастрову) та реєстрації прав на землю (юридичну), відомості якої мають багатоцільове призначення та використання.

Фактично від ефективності обліку, достовірності і правильності інформаційної бази залежить результативність управління. При цьому облік кількості та якості земель і земельних ділянок залежить від таких складників:

1) збір даних про земельні ресурси, земельні ділянки та землекористування;

2) формування і створення інформації, придатної для передачі по каналах зв'язку в керуючу систему та/або обробки в автоматизованому режимі;

3) своєчасна та безпечна передача достовірної інформації про земельні ресурси (ділянки) [8, с. 24].

Проведення обліку земельних ресурсів, наявність вірогідних і точних даних, які стосуються розмірів земельних ділянок та інших якісних і кількісних характеристик, що містяться у книгах державної земельної реєстрації, $є$ надійною підставою для захисту у разі порушення прав землевласників або землекористувачів.

Враховуючи викладене, необхідно відзначити публічно-правовий характер суспільних відносин, що виникають у сфері обліку земельних ресурсів. Окрім того, в умовах проведення земельно-реєстраційної реформи та подальшого процесу удосконалення Державного земельного кадастру необхідно вести мову про існування земельно-інформаційних відносин.

Слід зауважити, що вектор, який був задекларований Україною, на забезпечення сталого та планомірного розвитку земельно-правових норм визначає необхідність у формуванні системи ефективного обліку земельних ресурсів. Це повинно бути 
забезпечено базовими методологічними принципами, серед яких - принципи екологічної та соціально-економічної результативності обліку та використання земель, а також забезпечення позитивної динаміки їх використання. Тобто ефективна управлінська система обліку земельних ресурсів повинна передусім забезпечити оптимальну комбінацію вищевказаних принципів задля забезпечення справедливого, відтворювального та безпечного розвитку не лише сільських територій, а й усього суспільства. Відповідно, це зумовлює необхідність комплексного підходу до вирішення проблем щодо реформування на ринкових засадах земельних відносин через призму управлінських та економічних реформ у нашій державі [3, с. 20].

\section{Висновки}

Таким чином, на основі проведеного дослідження можна зробити висновок про необхідність та актуальність удосконалення законодавства щодо обліку та реєстрації земель. Зокрема, нагальним видається законодавче визначення поняття обліку земель, а також у земельному законодавстві повинен бути передбачений чіткий дієвий механізм ведення обліку та реєстрації земельних ділянок, оскільки у вітчизняних облікових стандартах відсутня чітка законодавча регламентація обліку землі, яка має різне цільове призначення, а також прав користування такими земельними ресурсами.

Також треба зазначити, що законодавство у сфері облікової діяльності стосовно земельних ресурсів має постійно оновлюватися, а окремі нормативно-правові акти та їх положення не повинні суперечити один одному. При цьому усі зміни до спеціального законодавства повинні мати систематичний і комплексний характер.

Важливого значення набуває запозичення позитивного міжнародного законодавчого досвіду у сфері обліку земельних ресурсів та його адаптація до сучасних реалій розвитку української держави.

Не менш важливим видається питання яке стосується використання науково обгрунтованого методу щодо ведення обліку землі, який може суттєво підвищити рівень наповненості облікових даних у Державному земельному кадастрі та зведе до мінімуму їх недостовірність.

На мою думку, налагодження ефективного обліку земельних ресурсів 3 метою забезпечення ефективного земельно-правового адміністрування не лише сприятиме оптимізації процесів використання, відтворення й охорони земель задля задоволення попиту суспільства в обмежених ресурсах, а й забезпечить збалансований екологічний, соціальний й економічний розвиток земельних правовідносин у довготривалій перспективі.

\section{Список використаних джерел:}

1. Земельний кодекс України від 25.10.2001 року № 2768-III. URL: https:// zakon.rada.gov.ua/laws/show/2768-14 (дата звернення: 23.02.2020)

2. Іконицька I. А. Земельне право. Москва, 1969. $85 \mathrm{c}$

3. Кубах С. С. Земельна дилема. Харків. 2015. № 8. C. 17-21.

4. Лебедева Т. М. Облік земель: правовий аспект. Науковий вісник Дніпропетровського державного університету внутрішніх справ. 2012. № 2. С. $229-236$

5. Магазинщиков Т. П. Земельний кадастр : підручник. Львів, 1991. 452 с

6. Про Державний земельний кадастр : Закон України від 07.07.2011 № 3613-VI. Офіиійний вісник України. 2011. № 60. Ст. 2405.

7. Сакаль О. В. Облік земельних ресурсів як передумова ефективного земельного адміністрування. Геодезія, картографія і аерофотознімання. 2013. № 77. C. 57-61.

8. Сакаль О., Третяк Н. Напрями удосконалення земельного обліку як інституційної основи сталого розвитку територій. Землевпорядний вісник. 2014. № 5. С. 22-26.

9. Симонова К. В. Правовое обеспечение кадастрового учета земельных участков : автореф. дис. ... канд. юрид. наук: 12.00.06. Москва, $2010.81 \mathrm{c}$

10. Ситнік Т. М. Деякі правові аспекти обліку земель населених пунктів, зайнятих зеленими насадженнями. Часопис Київького університету права. 2015. № 2. С. 276-279.

11. Теоретичні основи державного земельного кадастру : навчальний посібник / М. Г. Ступень, Р. Й. Гулько, О. Я. Микула та ін.; за заг. ред. М. Г. Ступеня. 2-ге видання. Львів: «Новий Світ$2000 \gg, 2006.336$ c.

12. Чешев А. С., Фесенко И. П. Земельный кадастр : учебник. Москва: ПРИОР, 2000. 362 с.

The article deals with topical issues of effective balanced land registration in Ukraine. The elements of land accounting are analyzed for the purpose of complete and continuous, objective and systematic accounting of the specified legal category. Some issues of land accounting are investigated, as well as the basic concepts used in the field of land relations are summarized.

The article deals with the main purpose and tasks of expediency of land registration in the territory of Ukraine. Defects of methodological and methodological approaches to the construction of land cadastre 
accounting are identified. Ways of organizing analytical land accounting and expediency in introducing industry standards in land land accounting as a legal category are outlined.

Also, sufficient attention is paid to the need for correct and timely filling of the accounting and cadastral system with reliable information regarding the qualitative and quantitative characteristics of land resources (plots). The main problems in the formation and maintenance of land accounting of the quality of land resources are identified and the main directions are directed towards the solution of the mentioned issue.

In the work of land accounting is considered in terms of management function as an integral element of the mechanism of land administration. It is determined that with its help the optimal use and protection of land according to their intended purpose is ensured, taking into account all forms of ownership and management.

Structural analysis of the legal content of the basic concepts of accounting and cadastral categories used in the field of land legal relations is necessary for the identification and elimination of terminological errors, harmonization of the conceptual apparatus and contribute to the study of the state of land accounting.

The main purpose of the article is to investigate the main characteristics and accounting categories in the field of land relations in Ukraine, as well as to provide some recommendations on land registration in order to ensure effective land administration.

Key words: land accounting, land resources, accounting object, land relations, land plots. 